\title{
Saint Petersburg and Dostoyevsky's Diary of a Writer. On the Edge of a Literary Genre
}

\author{
Lenka Paučová \\ (Brno, Czech Republic)
}

\begin{abstract}
:
19th-century Saint Petersburg was a great inspiration for Russian writers. The paper is dedicated to the image of Saint Petersburg in the work of F. M. Dostoyevsky (1821-1881) who lived in the city most of his life. Saint Petersburg interconnects the entire Dostoyevsky's work from the early creation to his most significant works. The author of the paper concentrates on the Diary of a Writer, one of Dostoyevsky's late works, in which she examines the connection of the genre with the theme of the literary work. Through the genre of the Diary of a Writer, Saint Petersburg acquires a different role compared with the novels. Moreover, this work illustrates the ambivalence with which the writer perceived Saint Petersburg as his home.
\end{abstract}

\section{Key words:}

Russian literature; F. M. Dostoyevsky; Diary of a Writer; image of Saint Petersburg; concept of home; ambivalence; genre and theme 


\section{Introduction}

Saint Petersburg, often called the "Russian Athens"1, fascinated many 19th-century writers with its magnificence. Its monuments and architecture were captured in the works of A. S. Pushkin, M. Y. Lermontov or F. M. Dostoyevsky, while the busy Saint Petersburg avenues came alive in the works of N. V. Gogol, A. Bely and others.

Fyodor Mikhailovich Dostoyevsky lived in Saint Petersburg more than a third of his life. Although Saint Petersburg was not his native town, it played an important role in the context of his work. As the topos of Saint Petersburg interconnects most of Dostoyevsky's works, he regarded himself its genius loci. In our paper, we will be concerned with the image of Saint Petersburg as a home in the interpretation of F. M. Dostoyevsky and with references to places with which the writer's biography is connected. We will focus on the image of Saint Petersburg in Dostoyevsky's late work the Diary of a Writer, using two methods-biographical and comparative.

We want to answer the following questions: How did Dostoyevsky perceive Saint Petersburg-was it a home to him or just a place where the internal dramas of his characters took place? What is the function of the image of Saint Petersburg in the Diary of a Writer as a whole and in its partial sections? Regarding the literary genre, we will concentrate on the interconnection of Saint Petersburg theme with a particular genre and hence the roots of his choice.

\section{Saint Petersburg as a home}

Dostoyevsky did not explicitly refer to his home. He regarded Saint Petersburg as well as the whole of Russia as his home. His yearning for home became particularly apparent after leaving his home, in a forced labour camp where he could not write and abroad where the feeling of the loss of inspiration grew strongly. In our opinion, the writer's perception of home is thus more apparent on a metaphorical level.

F. M. Dostoyevsky's birthplace was Moscow where his father worked in a hospital for the poor from which the writer saw its dark side above all. The family estate of Darovoye (Даровое), which originally belonged to his mother, was another important place in Dostoyevsky's life. The Dostoyevsky family regularly visited it during the holidays. $^{2}$

1 Nikolai Pavlovich Anciferov's reference to Saint Petersburg "Петербург - это русские Афины. Стольный город русской духовной культуры” is originally based on his diary records. Cited according to [ANCIFEROV 1991, 6].

2 We can find reference to this estate in the Diary of a Writer dated April 1876 entitled Confusion and Inaccuracy of the Contradictory Points (Сбивчивость и неточность спорных пунктов) where Dostoyevsky recalls an incident from his childhood when the estate almost burned down. 
His life in Siberia, Omsk, Archangelsk and then Semipalatinsk was banishment because he could not fully dedicate himself to the literary activity as in Saint Petersburg, missing the contacts with writers and the literary life. Yet, he never regretted the time spent in the forced labour camp.

\section{Dostoyevsky in Saint Petersburg}

F. M. Dostoyevsky's attitude to Saint Petersburg and the role of the city in his work have been described by many authors. However, we wish to point at three principal monographs coming from secondary literature on the theme, in particular a chapter in the famous monograph Непостижимыци город by the Russian scientist N. P. Anciferov [ANCIFEROV 1991], Петербург Достоевского by V.S. Biron [BIRON 1991] and Достоевский в Петербурге by J. Saruchanyan from 1970 [SARUCHANJAN 1970]. We can find elaboration on the comparison with F. M. Dostoyevsky's novels in articles by W. Szczukin [SZCZUKIN 1984, 107-119] and with Charles Dickens in specialized articles by T. Jankowska [JANKOWSKA 2013, 45-55]. In addition to that, it is important to point out monographs by Western critics, G.S. Morson [MORSON 1981] and R. Vassena [VASSENA 2007]. The fact that students can find the issues of Saint Petersburg interesting is documented by a textbook on the 19th-century writers living in Saint Petersburg Петербург в жизни и творчестве русских писателей [GLAZUNOVA 2003] published in 2003.

The first contact of Dostoyevsky with Saint Petersburg occurred in 1838 when his father brought him there to study at a secondary school for army engineers (военно-инженерное училище). The young man joined the classes on 16 January 1838. However, Dostoyevsky later regarded his parents' decision a mistake. The school was based in the Mikhailovsky Palace, former residence of Paul I, and as a student, he knew all historical events which, as Evgenya Saruchanyan mentions, affected Dostoyevsky's first impressions of Saint Petersburg [SARUCHANJAN 1970, 12]. He completed the education in 1843 as the third best student.

Dostoyevsky regarded his life in Saint Petersburg as dark, hard and almost tragic. We can therefore refer to his attitude to the city as ambivalent. He wrote in his correspondence that the city would burn the man. This can be documented by a letter to his elder brother Mikhail Mikhailovich from 7 October 1846: "Петербург - ад для меня. Так тяжело, так тяжело здесь жить." [DOSTOJEVSKIJ 1985, 127]. In our opinion, Dostoyevsky's attitude to Saint Petersburg was ambivalent, the so-called Haßliebe $^{3}$ : adoration for its past and architecture on the one hand and negative

3 Ivo Pospíšil uses this term for ambivalent perception of the American milieu and Russian as the language in the novel Field Research into Ukrainian Sex (1998, Czech in 2001) by the Ukrainian writer Oxana Zabužko ( $\left.{ }^{*} 1960\right)$. Cf. [POSPÍŠIL, 2004, 45]. 
perception of its dark side-the life of the poor, homeless and drunks on the other hand.

Besides the correspondence, Dostoyevsky also referred to Saint Petersburg in the essay St. Petersburg Dreams in Verse and Prose. He said that in Saint Petersburg, he always felt lost and the city remained covered under the veil of secrecy: "Еще с детства, почти затерянный, заброшенный в Петербурге, я как-то боялся его; Петербург, не знаю почему, для меня всегда казался какою-то тайной." [DOSTOJEVSKIJ 1988, 482-502].

Saint Petersburg awoke ambivalent emotions in Dostoyevsky. On the one hand, fear and terror: "Мне кажется, это самый угрюмый город, какой только может быть на свете!” [DOSTOJEVSKIJ 1980, 111]. On the other hand, Saint Petersburg was a city to which he desired to return after the punishment of forced labour. The desire to live in the former capital culminated in impatience and negative perception of Tver where he waited for the permit. He was grateful to the tsar to the end of his life for giving him permission to return for which Dostoyevsky was criticized.

Dostoyevsky rented apartments at the corner of the streets, always near a church. He chose flats with windows facing street lamps to save money on candles. His first room-mate was doctor Riesenkampf who moved to the writer at the request of his elder brother Mikhail Mikhailovich. Later, in the years 1844-1846, Dostoyevsky shared his flat with the writer Dmitry Grigorovich. [SARUCHANJAN 1970, 28-34].

The yearning for home strongly resonated in Dostoyevsky's life abroad-not a particular place, but the whole Russia. He feared the loss of inspiration and yearned for contact with Russia. The negative impressions from the Western civilisation where Dostoyevsky saw nothing positive apart from the art, prompted him in 1863 to write an essay Winter Notes on Summer Impressions. In this work, the perception of Russia as a home is particularly apparent. To express his attitude to Saint Petersburg, F. M. Dostoyevsky used one of his last works-the Diary of a Writer.

\section{Saint Petersburg in Dostoyevsky}

Based on the nature of F. M. Dostoyevsky's work, we can claim that Saint Petersburg interconnects almost all of the writer's works. It was a scene where the drama of the poor man Makar Devushkin and the humiliated and insulted took place. Saint Petersburg caused the split of Golyadkin's personality when he created his double in his mind, where the birth of a man from the underground took place (подпольный человек), where the perfectly beautiful man (положительно прекрасный человек) Myshkin became so disappointed and where student Raskolnikov's idea was created. Saint Petersburg became a city where people believing in an ideal like Don Quixote always grew disillusioned. 
In Makar Devushkin, a character from the writer's first novel Poor Folk (Бедные $л ю \partial и, ~ 1846)$, we can see the image of a person strolling through Saint Petersburg streets meeting various types of people-officials, drunkards, prostitutes or organ grinders. According to Evgenya Sarukhanyan, the role of Saint Petersburg became a kind of a distinctive person since the issue of the Poor Folk: "Роман 'Бедные люди' положил начало тому, что впоследствии получило название 'Петербург Достоевского'” [SARUCHANJAN 1970, 46]. He pointed at the connection between the Double and Saint Petersburg with by the subtitle Saint Petersburg Poem. However, according to Alexander Blok, the novel most strongly connected with Saint Petersburg was Raw Youth [SARUCHANJAN 1970, 219]. On the other hand, the accentuation of Saint Petersburg topos appears in works on the edge of the genre, in a cycle of essay-like feuilletons St. Petersburg Dreams in Verse and Prose (Петербургские сновидения в стихах и прозе, 1861) published in the Vremya magazine and in the Diary of a Writer.

\section{Image of Saint Petersburg in Diary of a Writer}

The Diary of a Writer (Дневник писателя; 1873, 1876-1877, 1880 and 1881) is basically a synthetic polygenre work, which took almost five years to complete in three phases. ${ }^{4}$ In all phases of the Diary, we can find boundary genres like essays, feuilletons or memoirs, but Dostoyevsky also inserted the so-called small epic, i.e. genres of artistic literature, in the first and second phase.

In the Diary of a Writer, we can define a double illustration of Saint Petersburg-explicit or implicit. We can distinguish between two roles of Saint Petersburg as the city-a background and a central theme of the work. We perceive Saint Petersburg as a background to the social events in parts about the spreading Redstockist and Stundist sects ${ }^{5}$ and in parts dedicated to criminal cases of Kronenberg ${ }^{6}$

4 As we have said, the Diary of a Writer took about five years to complete in three phases: in 1873-1874 it was part of the Grazhdanin periodical, in 1876-1878 it was published as a separate periodical and in 1880 and 1881 only one issue was published.

5 Lord Redstock (Лорд Редсток), A Word to a Report on the Scientific Committee on Spiritual Phenomena (Словио об отчете ученой комиссии о спиритических явлениях) and other. The mentioned parts resound with Dostoyevsky's opinions. The writer arrives at a conclusion that success of people such as Redstock is based on separation of the nation from the soil.

6 It involves a series of the following articles from the Diary of a Writer dated 1876: Kronenberg Case (По поводу дела Кроненберга), A few Words about the Lawyers in General. My Naïve and Amateur Ideas. A few Words about the Talents in General and in Particular (Нечто об адвокатах вообще. Мои наивные и необразованные предположения. Нечто о талантах вообще и особенности), Speech by Mr. Spasovich. Artful Tricks (Речь г-на Спасовича. Ловкие приемы), The Berries (Ягодки), Hercules Columns (Геркулесовы столпы), Family and our Shrines. A few Words about one Young School (Семья и наши святыни. Заключительное слово об одной юной школе). 
and Kairova ${ }^{7}$. Compared with Dostoyevsky's novels, it is not just a background in the Diary and mainly in its feuilletons. It comes to the foreground when the city becomes the central theme. The 13th part of the Diary of a Writer from 1873 contains the feuilleton Little Pictures (Маленькие картинки) where Dostoyevsky describes Saint Petersburg as a city of contrasts: wooden houses of the poor on the one hand and houses of rich burghers on the other. ${ }^{8}$ As we can see, Dostoyevsky's ambivalence regarding his attitude to the city is also projected in a feuilleton from the Diary of a Writer. He highlights the glorious history of the city and its exceptional architecture ${ }^{9}$, which he compares with the undistinguished architectonic style of the present ${ }^{10}$; yet he also sees dangerous streets where the people can be knocked down by a cart with horses. The dark, dreary atmosphere of the city streets dominates.

The feuilleton also describes the main Saint Petersburg "thoroughfare", the Nevsky Prospect, emphasising the danger: "На днях переходил Невский проспект с солнечной стороны на теневую. Известно, что Невский проспект переходишь всегда с осторожностью, не то мигом раздавят, - лавируешь, присматриваешься, улучаешь минуту, прежде чем пуститься в опасный путь, и ждешь, чтобы хоть капельку расчистилось от несущихся один за другим, в два или три ряда, экипажей. Зимой, за два, за три дня перед рождеством, например, переходить особенно интересно: сильно рискуете, особенно если белый морозный туман рассвета опустится на город, так что в трех шагах едва различаешь прохожего." [DOSTOJEVSKIJ 1980, 105].

In his notes and feuilletons, Dostoyevsky often noted that he liked to watch unknown people and, examining their faces, tried to guess who they were, what they did for a living and what personality traits they had. ${ }^{11}$ In Little Pictures, he observed that people could live in dignity even in dark Saint Petersburg. He described the lives of ordinary people whom he was meeting-a boy with his father; a little girl who,

7 Namely the following articles: The Court and Mrs. Kairova (Суд и г-жа Каирова), Mr. Attorney and Kairova (Г-н защитник и Каирова), Mr. Attorney and Velikanova (Г-н защитник и Великанова).

8 “эти деревянные, гнилые домишки, еще уцелевшие даже на самых блестящих улицах рядом с громаднейшими домами и вдруг поражающие ваш взгляд словно куча дров возле мраморного палаццо.” [DOSTOJEVSKIJ 1980, 106].

9 Dostoyevsky perceives the city architecture as follows: “Удивительна мне этаархитектура нашего времени. Да и вообе архитектура всего Петербурга чрезвычайно характеристична и оригинальна и всегдапоражала меня, - именно тем, что выражает всю его бесхарактерность и безличность за всё время существования." [DOSTOJEVSKIJ 1980, 106].

10 “не знаешь, как и определитьтеперешнюю нашу архитектуру. Тут какая-то безалаберщина, совершенно, впрочем, соответствующаябезалаберности настоящей минуты.” [DOSTOJEVSKIJ 1980, 107].

11 “Я люблю, бродя по улицам, присматриваться к иным совсемнезнакомым прохожим, изучать их лица и угадывать: кто они, как живут, чем занимаются и что особенно их в эту минуту интересует." [DOSTOJEVSKIJ 1980, 111]. 
running after her mother, stepped on her skirt. Dostoyevsky accentuated the main idea of the feuilleton in the fourteenth part of the Diary of a Writer entitled To the Teacher (Учителю) by responding to the criticism of a Moscow feuilleton writer who blamed him for writing the feuilleton only to get as many readers as possible. Yet Dostoyevsky wanted to emphasise that even people of modest means were able to keep their pride and love for family and children. ${ }^{12}$

We can compare a detailed description of the main Saint Petersburg thoroughfare from Dostoyevsky's feuilleton with the description of N. V. Gogol in his novel Nevsky Prospect (Невский проспект, 1835). Like Dostoyevsky, Gogol described various types of people in the main street, but he accentuated objects ${ }^{13}$ that characterised the street as follows: "Все, что вы ни встретите на Невском проспекте, все исполнено приличия: мужчины в длинных сюртуках, с заложенными в карманы руками, дамы в розовых, белых и бледно-голубых атласных рединготах и шляпках. Вы здесь встретите бакенбарды, единственные, пропущенные с необыкновенным и изумительным искусством под галстук, бакенбарды бархатные, атласные, черные, как соболь или уголь [...]" [GOGOL'2002, 4].

As we have mentioned, the milieu of Saint Petersburg can be illustrated explicitly or implicitly. The story Beggar Boy at Christ's Christmas Tree (Мальчик у Христа на Елке) represents the second way of illustration. According to Saruchanyan, the text of this short story includes hints pointing at Saint Petersburg although the author did not refer to it. [SARUCHANJAN 1970, 226].

\section{Saint Petersburg and the literary genre}

In the Diary of a Writer as regards its connection with Saint Petersburg, we will be concerned with the interconnection of this theme with a particular literary genre. We have to point out that the Diary of a Writer is a unit composed of parts. If we apply a teleological approach to the genre and view the Diary of a Writer as a whole, we can refer to it as a diary, which accentuates the space "beyond me"-the city, atmosphere

12 F. M. Dostoyevsky expresses the main idea of the Little Pictures in the following part of the Diary of a Writer: "в огромном большинстве народанашего, даже и в петербургских подвалах, даже и при самойскудной духовной обстановке, есть все-таки стремление к достоинству, к некоторой порядочности, к истинному самоуважению; сохраняется любовь к семье, к детям. Меня особенно поразило, что они так действительно и даже с нежностию любят своих болезненных детей; я именно обрадовался мысли, что беспорядки ибесчинства в семейном быту народа, даже среди такой обстановки, как в Петербурге, всё же пока исключения, хотя, бытьможет, и многочисленные, и думал поделиться этим свежим впечатлением с читателями." [DOSTOJEVSKIJ 1980, 113].

13 Based on the description of objects that become the dominants of the characters, Andrej Červeñák considers N. V. Gogol a representative of the so-called social stream or tangible realism (in Slovak sociálny prúd, predmetový realizmus). Cf. [ČERVEŇÁK 1994]. 
of the time, interpersonal relations, etc. However, if we view the Diary through its parts, we also need to acknowledge the genre of these parts. In the given context, the space of the city is mostly accentuated by genres of factual literature, in particular journalistic genres, i.e. feuilleton in case of the Diary of a Writer. The Diary of a Writer as a whole thus allows us to see Saint Petersburg on several levels: external character of the city (architecture, pictures of the streets and the main thoroughfare), its internal character, i.e. social events connected with Saint Petersburg (sects, criminal cases), the life of Saint Petersburg citizens (interpersonal relations of poor people, drinking, child mortality) and feelings of the actual writer (the city atmosphere, famous past, darkness, danger).

As mentioned above, the Diary of a Writer contains genres of artistic and factual literature. In addition to the genres of artistic literature (short essays, stories and novellas), the partial sections open ground for highlighting the city space and the atmosphere of the time. In the feuilletons, Saint Petersburg becomes the main theme of the literary work. In other words, the "centre of gravity" shifts from the characters to the milieu, thus, in our opinion, determining the author's choice of the literary genre.

We answer the question of whether the theme affects the choice of the literary genre affirmatively: in order to accentuate the milieu, the author will not choose a novel, but a genre that enables the description and focus on the milieu. Dostoyevsky chose a boundary genre-a diary, namely the writer's diary because one of its most important features, the so-called polymorphous span (a term used by I. Pospíšil), ${ }^{14}$ allows integration of other genres focused on the space in the genre structure, thus accentuating the role of the mentioned milieu.

In the role of a background, Saint Petersburg appears in short journalistic genres such as short essays depicting judicial processes with Kronenberg and Kairova, investigation of other criminal cases or suicides that shook the public, essays on the spread of the Redstockist and Stundist sects or memorial and apologetic essays related to Dostoyevsky brothers' cooperation in the Vremya and Epocha magazines. In the mentioned short essays, Dostoyevsky explicitly named the milieu and constantly referred to the scene of the ongoing events as Saint Petersburg. For example, in Two Suicides (Два самоубийства), the death of the seamstress Marya Borisova who committed suicide on 30 September 1876 by jumping out of the window with an icon of the Mother of God in her hand, is linked to Saint Petersburg. Dostoyevsky compares the suicide of Borisova, a Saint Petersburg citizen, with a tragic event in Florence where the daughter of the famous writer A. I. Herzen Yelizaveta committed

14 Ivo Pospiśil uses the term polymorphous span to express multiple genres, the so-called polygenre. See [POSPÍŠIL 1992]. 
suicide. We believe that it is no coincidence that the suicide that took place in Saint Petersburg was significant to the Diary of a Writer and that her protagonist became a prototype for the female character in the novel Timid. We can thus see how the writer maintained his connection with Saint Petersburg.

The mentioned examples illustrate that in the role of a background, Saint Petersburg accentuates only some of the levels that we pointed out at the beginning of the essay: in Lord Redstock and the Kronenberg or Kairova cases, it completes the internal character of the city, the Two Suicides novel concerns the Borisova case that shook Saint Petersburg and the actual writer is connected with the essay In Defence of the Dead. In the role of a central theme, Saint Petersburg is connected with the feuilleton Little Pictures and its sequel To the Teacher. The feuilleton as a genre accentuates the perception of the Saint Petersburg atmosphere on almost all of the mentioned levels, in our opinion with emphasis on the writer's impressions.

\section{Conclusion}

Dostoyevsky spent most of his life in Saint Petersburg. It became his home for more than 20 years although he perceived it ambivalently and his characters more or less negatively. The writer desired to return to Saint Petersburg from the forced labour camp and in particular from a four-year tour round the West. Dostoyevsky's yearning for home in the foreign countries was no longer related to a particular town, but to the whole of Russia.

As we can see, Dostoyevsky's ambivalence to Saint Petersburg is projected into his works. On the example of feuilletons in the Diary of a Writer, we can observe veneration of the city on the one hand and fear and insecurity that the city inspired on the other hand. In the feuilleton Little Pictures located in the Diary of a Writer, we can find a detailed description of the main Saint Petersburg thoroughfare, which is comparable with a description in Nevsky Prospect by N. V. Gogol.

Based on the mentioned examples, we have arrived at the conclusion that the work's theme affects the choice of the literary genre. As regards the genre, the Diary of a Writer is a specific work that can be seen in two perspectives. The actual genre of a diary allows accentuation of the space, but in our opinion, its most significant accentuation is achieved by the use of factual literature, namely the feuilletons inserted in the Diary of a Writer. 


\section{References:}

ANCIFEROV, N. P. (1991): Nepostižimyj gorod. Duša Peterburga. Peterburg Dostojevskogo. Peterburg Puškina. Sankt-Peterburg.

BIRON, V.S. (1991): Peterburg Dostojevskogo. Grav. na dereve N. Kofanova. Leningrad. ČERVEŇÁK, A. (1994): Zázračno literatúryI. Ruská klasika. Nitra.

DOSTOJEVSKIJ, F. M. (1980): Polnoje sobranije sočinenij v tridcati tomach. Tom dvadcat' pervyj. Dnevnik pisatelja 1873. Leningrad.

DOSTOJEVSKIJ, F. M. (1985): Polnoje sobranije sočinenij v tridcati tomach. Tom dvadcat' vos'moj. Publicistika i pis'ma. Pis'ma 1832-1859. Leningrad.

DOSTOJEVSKIJ, F. M. (1988): Peterburgskije snovidenija v stichach i proze. In: Polnoje sobranije sočinenij v pjatnadcati tomach. Leningrad, pp. 480-522. <https://rvb.ru/ dostoevski/o1text/vol3/2o.htm>. [online]. [cit. 25. 2. 2020].

GLAZUNOVA, O. I. (2003): Peterburg v žizni i tvorčestve russkich pisatelej. Sankt-Peterburg. GOGOL', N. V. (2002): Povesti. Moskva-Augsburg.

JANKOWSKA, T. (2013): O wzajemnych relacjach kategorii przestrzeni i postaci w tekście miasta Charlesa Dickensa i Fiodora Dostojewskiego. Przegląd rusycystyczny, 2013, Nr. 3, pp. 45-55.

JANKOWSKA, T. (2014): The Artistic Space of Home in Fyodor Dostoyevsky's Novel Crime and Punishment. The Interface between Semiotics and Translation. Przegląd Rusycystyczny, 2014, Nr. 1, pp. 27-45.

KRYSTEVA, D. (2010): Krokodil F. M. Dostojevskogo kak peterburgskaja povest'. (Zametki $k$ slovarju allegorij peterburgskoj istorii). Acta Universitatis Lodziensis. Folia Litteraria Rossica Vol III, 2010, pp. 60-68.

MORSON, G. S. (1981): The Boundaries of Genre. Dostoevsky's "Diary of a Writer" and the Traditions of Literary Utopia. Evanston.

PAUČOVÁ, L. (2017): Na margo výzkumu žánru deníku ve slovanském prostředí. Slavica litteraria Vol. XX, 2017, Nr. 2, pp. 95-102.

POSPÍŠIL, I. (2004): Studie o literárních směrech a žánrech. Banská Bystrica.

POSPÍŠIL, I. (1992): Rozpětí žánru. Brno.

SARUCHANJAN, E. (1970): Dostojevskij v Peterburge. Leningrad.

SZCZUKIN, W. (1984): Petersburg a twórczość Fiodora Dostojewskiego. Rocznik Komisji Historycznoliterackiej Vol. XXI, 1984, pp. 107-119.

VASSENA, R. (2007): Reawakening of National Identity. Dostoevskii's Diary of a Writer and Its Impact on Russian Society. Bern.

\section{About the author}

Lenka Paučová, University of Defence, Language Training Centre, Brno, Czech Republic, lenka.paucova@unob.cz 